\title{
Research and Practice of Software Engineering Students' Creative and Practical Ability Training Mode
}

\author{
Wu XiuQin \\ School of Computer \& Information Technology of \\ Northeast Petroleum University \\ DaQing, China \\ e-mail: wxqltl@163.com
}

\author{
Liu TieLiang \\ School of Computer \& Information Technology of \\ Northeast Petroleum University \\ DaQing, China \\ e-mail: ltldqpi@163.com
}

\begin{abstract}
Software engineering has strong demand to students' practical operating ability. However now, students' learning and innovation practice ability are not positively related to the trend. How can this phenomenon appear? Well, our talent training model at present is responsible to it. In other word, we can say that too-much-emphasize-on-single and mainly-learning talent training model leads to some problems. In this article, some proposals have been put forward to reform software engineering students' creative and practical ability training mode, such as, generally prompt innovation practice quality education following the instruction of the scientific educational concept, punning the basis of students' innovation practice ability training on the basis of optimizing the course system, build a student after-class science and technology activity model on the purpose of training students' innovation practice ability, and so on.
\end{abstract}

Keywords- Engineering Education; Higher Engineering Education; Engineering Practice

\section{INTRODUCTION}

Software engineering has strong demand to students' practical operating ability. However now, students' learning and innovation practice ability are not positively related to the trend. Students can gain knowledge and improve their quality by learning, but their innovation practice ability isn't improved yet. The phenomenon of "high scores and low abilities" is along with most college students. From the feedback information of employers, many graduates are lacking of the consciousness and ability of innovation, and they can't find the problems actively in practice, what's more, they can't come out of solutions to solve the problems or do it innovatively even they meet with the problems. So we can find that students may not develop corresponding innovation practice ability even they have got knowledge and improved quality, which means knowledge, quality and innovation ability is not corresponding relationship between equivalents. How can this phenomenon appear? Well, our talent training model at present is responsible to it. In other word, we can say that too-much-emphasize-on-single and mainly-learning talent training model leads to some problems in students' study as follows: more attention to knowledge than ability, remembering than thinking, inheritance than innovation, theory than practice, standardization than individuation, and outside stimulation than inside impelling and so on. This kind of training model is really helpless to students' changing knowledge and quality into innovation practice ability. In order to achieve that purpose, we have to change the student innovation practice ability training model[1].

II. GENERALLY PROMPT INNOVATION PRACTICE QUALITY EDUCATION FOLLOWING THE INSTRUCTION OF THE SCIENTIFIC EDUCATIONAL CONCEPT

In order to improve students' innovation practice ability, firstly, we have to refresh our education concept and reform the teaching idea.

\section{A. Apply the Scientific Teaching Method and Train Students' Innovation Spirit}

Stick to enlightening teaching, pay attention to the training of students' innovative thinking and study ability. For example, students can decide their own subjects and finish their relevant course projects, which can not only stimulate students' interests but also enlighten them to finish their projects with what they have learned[2]. We have got twofold results with half effort about study effect. At the same time, we also train students' interests about science technology innovation and arouse their passion about innovation[3]. Teachers have to combine their knowledge teaching with innovation ability training, and pay attention to comprehensive training taking account of individual ones. Moreover, teachers should help students to form better mental quality, and care about and encourage them to come up with some innovative questions and idea, which can give students, chances to show their innovation ability fully. Besides, teachers have to make the science and technology spirit run through the whole process of their teaching, and let moral character education along with knowledge teaching, and pay attention to train students' strict attitude to study and a scientific outlook on life and a better volitional quality[4].

\section{B. Set Up the Scientific Education Idea and the Student's Main-body Status}

Teachers in modern college are not only those who have encyclopedically basic knowledge, intensive special knowledge, good teaching study ability and teacher's professional quality and character, but they also set up an idea that is both coincident to teaching rules and social development modern education and teaching[5]. What's more, they establish the idea of students' subject and insist to carry out it, by respecting and believing in them and letting them develop actively and lively. 


\section{Set Up the Scientific Teaching Quality Idea and Make} an Atmosphere in which Students Are Innovative

We have to make the innovation practice ability an important according in measuring students, and see the students' innovation spirit and practice ability as our teaching standard in teaching management. Moreover, we have to use the direction of teaching evaluation and try to make a good environment for students to do some science technology innovations, and we are trying to make an active, lively and practical campus science technology innovation atmosphere with freedom[6]. In addition, we should make students science technology innovation practice education run through the whole process of talent training, and adopt it in students' comprehensive program, and make the innovation education combined closely with professional education, in order to develop students with higher comprehensive quality of broad-caliber, thick-foundation and new content and science technology innovation spirit according to the demand of our social development.

\section{PUNNING THE BASIS OF STUDENTS’ INNOVATION PRACTICE ABILITY TRAINING ON THE BASIS OF OPTIMIZING THE COURSE SYSTEM}

\section{A. Students' Innovation Practice Ability Training System is the Policy of Student Innovation Practice Ability Training}

The protocol of students' innovation practice ability training system is showed by Figure 1 . In addition of the means we always emphasize such as building science technology innovation lab and base, and participating in all kinds of subject competitions actively, we also add some content such as engineering ability training and humanistic quality training in this training system[7].

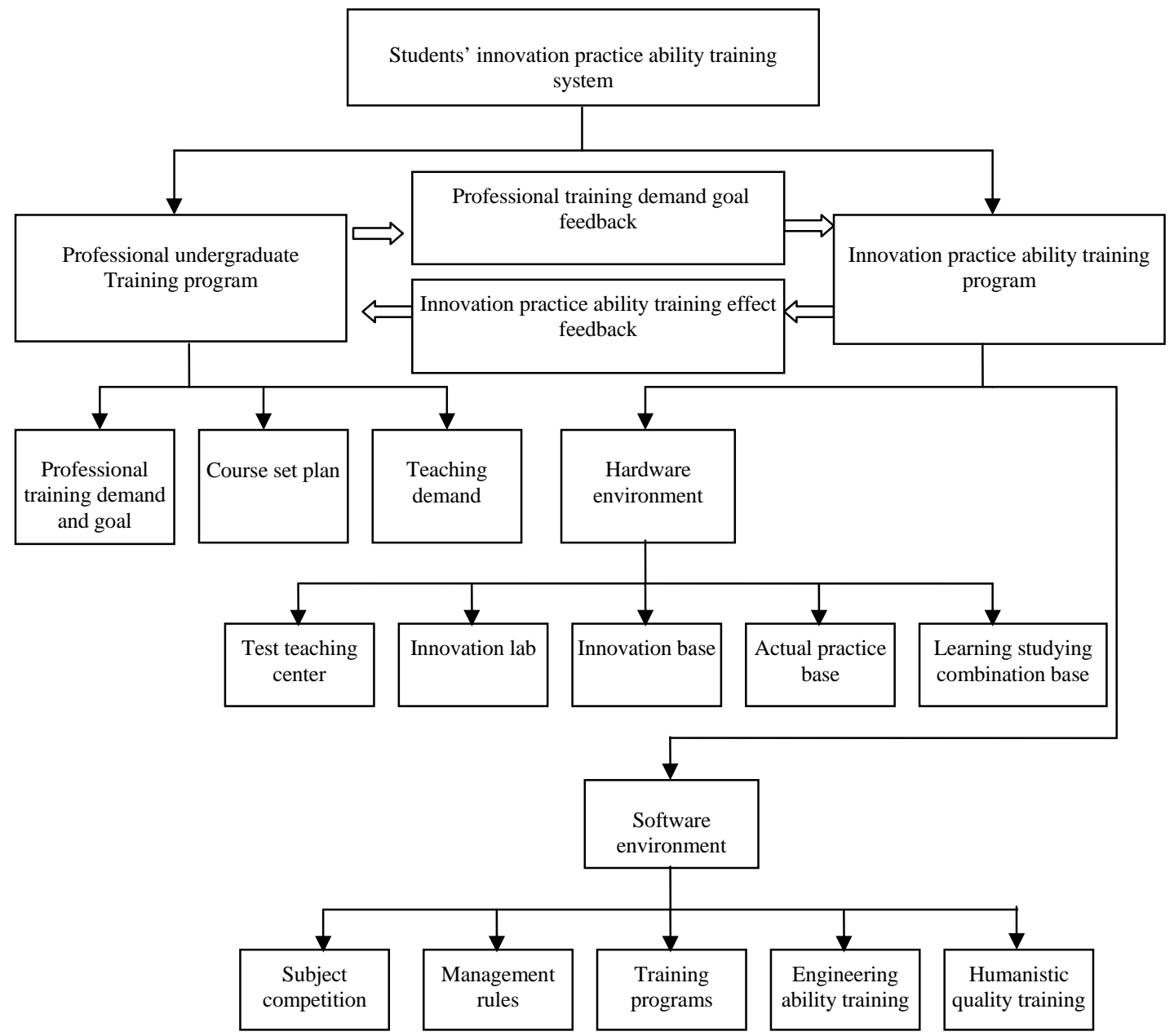

Figure 1. students’ innovation practice training system

Engineering ability training is mainly to build a correct idea of engineering values for students and improve their engineering ability. There is a bigger problem in software- majoring students understanding of engineering subjects: Firstly, as for undergraduates, most of them would have a one-side thought that engineering subjects are too much large 
and the content is complex include many courses. What's more, the engineering subjects will cost too much time and need many people to finish it. The usual problems in finishing these subjects will make most students be terrified of the engineering subjects or programs. Even this kind of study attitude can low students' initiative and creativity. Besides, students lack power to study, which means they neither have the interest to study actively nor have the arrangement ability of their time. According to the above problems, we have to pay more attention to train students' idea of engineering values in our course teaching, and help them to realize that engineering is a non-stop process of willing to be outstanding, and we must create and explore the idea through much revisions and corrections in this process.

Humanistic quality training is mainly to train students' cooperation and community abilities. Software developing is a collective wisdom of a team, and cooperation and communication play an important role in the process. Nowadays, as many families have only one child, many students are independent at most time and they like to show their own ability but are weaker in cooperation and communication. We can enhance their training about these two aspects through all kinds of ways.

\section{B. Responsible and Scientific Course System Is a Promise to Train Students' Innovation Practice Ability}

Software professional course system should pay attention to students' mastering the main professional knowledge and technology, and let them have some useful technical expertise. Through the multi-level practice, students will have the ability which software engineers use to work on engineering practice. Course system should show the characters that we pay more attention to our basis and skills and have more practice. The course module can be divided into several modules such as public course module, professional course module, practical course module and IT authentication course. On the basis of the basic courses which regard ramming mathematical foundation as the key to set up such as mathematics analyze and high algebra, we will open professional basic targeted courses in order to make a basic for further next-step study of professional courses, and offer the professional and introduction knowledge. The practical course module is a multi-level practical teaching system includes course test, course training, subject training, enterprise training, enterprise engineering training and graduation design, and it runs through the whole process of professional course module teaching. We have to train students to master comprehensively and apply the new knowledge and technology of modern science technology development, so as to improve students comprehensive scientific study quality[5].

\section{BUILD A STUDENT AFTER-CLASS SCIENCE AND TECHNOLOGY ACTIVITY MODEL ON THE PURPOSE OF TRAINING STUDENTS’ INNOVATION PRACTICE ABILITY}

\section{A. Try to Improve Students' Professional Skills by Subject Competition}

Students have to participate in all kinds of software engineering relevant subject competition such as the ACM Software Design Competition and The National Software Competition and so on. We have got many feelings through these competitions, and they let us gain full insight that this kind of professional-knowledge-basic science and technology activity is the improvement of students' professional knowledge, the training of innovation ability and the best way to practice working ability.

\section{B. Try to Improve Students' Innovation Practice Ability with the Help of Innovation Labs}

Innovation labs provide students another stage to train students' innovation practice ability. We can build different labs according to the professional characters of software engineering. And these labs' directors are teachers while students are their own managers. Students can finish the plan program by themselves or in cooperation while teachers just give them proper direction, which gives students chances to practice and trains their comprehensive ability to analyze and solve complex problems, so that students' overall qualities to solve actual problems can be improved[8].

\section{Try to Improve Students' Comprehensive Quality by Starting After-class Science and Technology Activities}

Starting after-class science and technology activities has enriched the campus academic atmosphere and encouraged students to combine theory with practice, and it leads students from theory to practice. Students' comprehensive quality can be improved through comprehensive application of knowledge and cooperation of team, and students' abilities of working, cooperation and innovation get trained as well.

\section{PROMPT STUDENTS' INNOVATION PRACTICE ABILITY TRAINING TAKING IMPROVING THE INNOVATION MANAGEMENT OPERATION MECHANISM FOR SECURITY}

\section{A. Improve the Encouragement and Management Mechanism}

Powerful innovation encouragement system is the basic assurance of students' innovation practice ability training. In order to build the encouragement system focused on training students' innovation practice ability fast and mobilizing students' passion to take part in after-class science and technology activities, we should organize regular college students' science and technology innovation models and give them priority in getting scholarship. We can lead students' innovation practice training into a healthier and sustainable way with the passion from all sides mobilized by the encouragement mechanism. 
Strengthen the construction of students' science and technology innovation organization .It plays an important role in students' daily after-class science and technology activities, and it is benefit for students to be active and positive while training their innovation ability. Moreover, it can attract more students to participate into the activities and train their innovation spirit and improve their innovation quality.

\section{B. Change the Student Evaluation System}

Accept the idea of education variety and see the students' differences with a scientific and equal attitude. When it comes to the evaluation of students' development and ability, we should set up of multi-level goal of poly style and find a way of variety development and innovation through different examples, in order to enlighten every student and let them find a proper way to success. To encourage students to participate in science and technology activities actively, we can take their competition results account for the comprehensive qualification and take scores as their encouragement.

\section{CONCLUSION}

We can find that students may not develop corresponding innovation practice ability even they have got knowledge and improved quality, which means knowledge, quality and innovation ability is not corresponding relationship between equivalents. In order to help the students to change knowledge and quality into innovation practice ability, we have to change the student innovation practice ability training model.

\section{REFERENCES}

[1] Liu JiZhen, “Curriculum reform: A View from Engineering”, Higher Education of China, 2009, pp.186-187.

[2] Zhang WenXun, "Development of Engineering Education Accreditation System and Its Potential Impact on Higher Engineering Education”, Tsinghua Journal of EducationT, 2009, pp.24-26.

[3] Zhang Hui, "Research of Computer Experimental Teaching Mode Based on CDIO”, Research and Exploration in Laboratory, 2011, pp. 23-38.

[4] Cha JianZhong, “A New Direction for Teaching Reform in Colleges and Universities”, Higher Education of Sciences, 2011, pp.9-12.

[5] Wang Gang, "Engineering Education Reading and Thinking Mode”, Higher Education of China, 2011, pp.86-87.

[6] Yang Jie, "Exploration of China Higher Engineering Education Undergraduate Teaching Management and Countermeasure”, Northeastern University, 2010, pp. 23-38.

[7] Zhang SheRong, "Exploration of reform of graduation project faced on enterprise needs”, Experimental Technology and Management, 2011, pp.89-93.

[8] Chen WenSong, "Engineering Education Major Certification and Its Influence on Higher Engineering Education”, Higher Education Forum, 2011, pp. 86-90. 